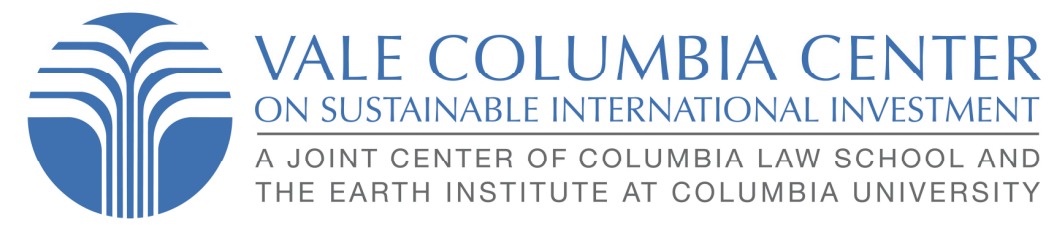

\author{
Columbia FDI Perspectives \\ Perspectives on topical foreign direct investment issues by \\ the Vale Columbia Center on Sustainable International Investment \\ No. 11, August 17, 2009 \\ Editor-in-Chief: Karl P. Sauvant (Karl.Sauvant@law.columbia.edu) \\ Editor: Lisa Sachs (Lsachs1@law.columbia.edu) \\ Special Editor for this Issue: Vishwas Govitrikar (Vishwas.Govitrikar@law.columbia.edu $)$
}

\title{
Indian FDI falls in global economic crisis: Indian multinationals tread cautiously by Jaya Prakash Pradhan*
}

Just over a year ago, outward foreign direct investment (OFDI) from India seemed to be on a path of rapid and sustained growth. Its annual average growth of 98\% during 2004-07 had been unprecedented, much ahead of OFDI growth from other emerging markets like China (74\%), Malaysia (70\%), Russia (53\%), and the Republic of Korea (51\%), although from a much lower base. Much of this recent growth had been fuelled by large-scale overseas acquisitions, however, and it faltered when the global financial crisis that started in late 2007 made financing acquisitions harder.

How will internationalizing Indian firms deal with the global crisis? Will they benefit from the global meltdown - for example, from cheaper asset prices - or become cautious and retreat?

\section{Slowdown in 2008, with dim prospects for 2009}

The global economic crisis has made Indian firms wary of further expansion abroad. Consequently, actual Indian FDI outflows, which rose to a historic level of nearly USD 18 billion in 2007, fell by 6\% in 2008 to under USD 17 billion (annex table 1). ${ }^{1}$ This is the first absolute decline in OFDI since 1999. The fall in Indian OFDI is in line with the worldwide decline of $15 \%$ in $2008,{ }^{2}$ although it contrasts with China's doubling of its OFDI in 2008. ${ }^{3}$ The contraction in Indian OFDI is continuing in 2009, falling to USD 4.7 billion in the first quarter of the current year, a $14 \%$ decline over the same quarter last year.

\footnotetext{
* Jaya Prakash Pradhan is Associate Professor at the Sardar Patel Institute of Economic \& Social Research in Ahmedabad, India, and may be contacted at pradhanjayaprakash@gmail.com. The author is grateful to Premila Nazareth and Ravi Ramamurti for their suggestions. The views expressed in this article do not necessarily reflect the opinions of Columbia University or its partners and supporters. Columbia FDI Perspectives is a peerreviewed series.

${ }^{1}$ The Reserve Bank of India (RBI), from which these figures are taken, tends to underestimate FDI in general, as it does not count re-invested earnings.

${ }^{2}$ UNCTAD (2009), "Global crisis now having strong, wide impact on foreign direct investment, study shows", Press Release, UNCTAD/PRESS/PR/2009/020, May 20.

${ }^{3}$ Kenneth Davies (2009), “While global FDI falls, China's outward FDI doubles", Columbia FDI Perspectives, No. 5, May 26, at www.vcc.columbia.edu.
} 
The trend in Indian overseas acquisitions in January-June 2009, as compared to the corresponding period in 2008, confirms the decline. Between these two periods, the value of such acquisitions fell by $65 \%$, from USD 8 billion to under USD 3 billion, and their number fell from 140 to 28 (annex table 2).

This 2008 and early 2009 plunge in Indian OFDI has been asymmetrical across sectors and host regions (annex tables 3, 4 and 5). Indian OFDI in the primary and tertiary sectors has been more resilient in the crisis than OFDI in manufacturing. Between 2007 and 2008, acquisition-led ${ }^{4}$ Indian OFDI grew in the primary sector (10\%) and in services (19\%), while it fell steeply in manufacturing (-79\%). The share of manufacturing in Indian OFDI flows thus fell, unsurprisingly, from 84\% in 2007 to $49 \%$ in 2008. The share of the primary and services sectors in Indian brownfield (i.e., made through mergers and acquisitions) OFDI, on the other hand, grew to $20 \%$ and $31 \%$, respectively. In the first half of 2009, the negative impact of the global slowdown spread to the services sector as well. Only the primary sector remained robust, led by ongoing increases in OFDI in the oil segment and the revival of OFDI in mining.

The current decline in Indian investment is widespread among recipients. Among host regions, the fall in Indian brownfield investment was steepest in the developing world (-79\%) in 2008, with Asia, which had accounted for $8 \%$ of the investment in 2007, falling by $85 \%$ in 2008 (annex table 4). Africa did much better, by receiving 69\% more brownfield investment in 2008, but this from a very low base of USD 111 million. Acquisitions in the developed world in 2007 had been led by Europe and fell by nearly 54\% in 2008. In North America, they fell by $75 \%$.

In the first half of 2009, Indian FDI flows into Africa were sharply higher than the first half of 2008, because of the region's oil and gas resources, while they fell in all other regions. Looking at countries, the two countries accounting for most of the value of Indian acquisitions in both 2007 and 2008 differed sharply in 2009. Indian brownfield investment in the United States during the first half of 2009 actually grew by $6 \%$ over the first half of 2008, while it fell by $99 \%$ in the United Kingdom.

Undertaken mostly by private enterprises, except for a few public-sector firms in the energy sector, ${ }^{5}$ Indian OFDI has been driven by several factors, including global growth, business opportunities and increased competition. The effect of market conditions turning adverse in 2008 can be seen in the actions of such Indian companies such as Sakthi Sugars, Reliance Industries, Vardhman Polytex, and Suzlon Energy, which are reportedly wrapping up (or disinvesting from) some of their overseas affiliates because of the current economic meltdown (annex table 6).

\section{What led to the downturn?}

Several factors account for the decline in Indian OFDI. The global and domestic slowdown in growth was one of these. The advanced economies are predicted to see a sharp fall in their aggregate real GDP growth rate from $2.7 \%$ in 2007 to $0.8 \%$ in 2008 and $-3.8 \%$ in 2009, signifying further reduction in overseas demand. ${ }^{6}$ Real GDP growth within India fell from above 9\% in October-December 2007 to just 5\% in

\footnotetext{
${ }^{4}$ Much of the discussion in this Perspective draws on data on M\&As compiled by the author. As the funds used for cross-border acquisitions need not come just from the home country, the sectoral and geographic distribution of such acquisitions may be different from the distribution of direct investment from India. The reason for using the M\&A data in this context is that data on the distribution of OFDI proper is not available.

${ }^{5}$ For a list of large Indian outward investors, see "The growth story of Indian multinationals", The Indian School of Business (ISB) and the Vale Columbia Center on Sustainable International Investment (VCC), 2009, at www.vcc.columbia.edu.

${ }^{6}$ International Monetary Fund (2009), "World economic outlook update”, July 8, 2009, http://www.imf.org/external/pubs/ft/weo/2009/update/02/index.htm.
} 
October-December 2008. This has led to an erosion of business confidence, reduced consumption and slowing investment, choking off both the domestic and overseas expansion of Indian firms.

The credit crunch in both Indian and overseas markets was another factor. Although the Indian banking sector did not suffer quite as much from its exposure to distressed global financial instruments and institutions as banks in some major economies, suffer it did and therefore adopted a cautious lending policy in $2008 .^{7}$ This in turn led to several domestic and overseas projects being postponed.

In addition, the global financial crisis had a significantly negative impact on other financial sub-sectors like the Indian equity, money and foreign-exchange markets. India's benchmark equity index, the Sensex, had fallen sharply by December 2008, by 48\% from its highest-ever level reached in December 2007. All this has restricted Indian firms' access to cheap sources of finance and reduced their profitability. Many Indian companies that had acquired overseas units in the recent past, such as Suzlon Energy, Tata Motors and Hindlaco, had to suspend their rights issues and faced difficulties in raising resources.

The sudden depreciation of the Indian rupee against the US dollar in 2008 also led to heavy losses for many export-oriented Indian companies that had acquired long-term forex derivatives. ${ }^{8}$ Several Indian companies, which had borrowed heavily abroad to finance their global acquisitions and greenfield projects during the period of rapid appreciation of the rupee against the dollar, encountered difficulties in meeting mounting overseas debt obligations after its sudden depreciation in late 2008. ${ }^{9}$ The depreciating domestic currency, combined with the collapsing stock prices of Indian companies, reduced these companies' ability to engage in M\&As.

Continued falls in export earnings, especially during October-December 2008, further aggravated the condition of export-dependent Indian firms in a large number of sectors, including software, gems and jewellery, leather, textiles, auto parts, pharmaceuticals, and food processing. Since exporters are leading outward investors, lower export earnings had a significant impact on Indian OFDI in 2008. The sudden collapse of commodity prices like crude oil, natural gas and metals also moderated the outward expansion of natural-resource-seeking Indian firms. Finally, anecdotal reports suggest that Indian firms with overseas affiliates - Bharat Forge, Havells India, Hindalco, Punj Lloyd, Tata Communications - have suffered severe consolidated losses in recent quarters on account of their overseas operations. ${ }^{10}$

\section{Future prospects}

Recovery in Indian OFDI will depend on the revival of global and domestic growth, improvements in corporate profitability, and the easing of financing from banks and the equity market. The first quarter of 2009 registered stronger GDP growth in India than expected, even though global growth went down. If domestic growth turns out not to be sustainable, however, OFDI may not recover.

Recently announced overseas deals, such as the proposed merger of Bharti Airtel and South Africa's MTN for USD 23 billion and Sterlite Industries' USD 1.7 billion bid for US-based copper-mining firm Asarco, suggest that 2009 might see some positive surprises. Moreover, not every Indian company has financing problems. There are some cash-rich Indian firms, including SMEs, which have not undertaken FDI in the past but may be interested in doing so in the future. These firms can be expected to explore acquisitions, given the cheap valuations of foreign assets.

\footnotetext{
${ }^{7}$ Hindu Business Line (2007), "Banks' loss due to sub-prime crisis put at \$2 b”, Saturday, October 6.

${ }^{8}$ Business Standard (2009), “46 companies suffer forex losses of Rs 1,365cr”, May 8.

${ }^{9}$ Pradhan, J.P. (2009) “The global economic crisis: impact on Indian outward investment”, MPRA Paper No. 1657, Munich University Library, Germany.

${ }^{10}$ Economic Times (2009), "Foreign acquisitions: No love across the border", April 20.
} 


\section{$\underline{\text { ANNEX }}$}

Annex table 1. Actual Indian FDI outflows, 2008 and early $2009^{\mathrm{a}}$

\begin{tabular}{|c|c|c|c|c|c|}
\hline \multirow{2}{*}{ Year } & \multirow{2}{*}{ Quarter } & \multicolumn{3}{|c|}{ FDI in USD million } & \multirow{2}{*}{$\begin{array}{l}\text { \% change over } \\
\text { previous year }\end{array}$} \\
\hline & & Equity & Loan & Total & \\
\hline \multirow{5}{*}{2008} & January-March & 3981 & 1422 & 5403 & 20.6 \\
\hline & April-June & 1346 & 451 & 1797 & -65.4 \\
\hline & July-September & 2640 & 494 & 3134 & 5.4 \\
\hline & October-December & 4254 & 1314 & 5569 & -2.0 \\
\hline & $\begin{array}{l}\text { All Quarters } \\
\text { (January-December) }\end{array}$ & 12926 & 3778 & 16704 & -6.3 \\
\hline 2009 & January-March & 4159 & 488 & 4647 & -14.0 \\
\hline
\end{tabular}

Sources: (i) RBI Bulletin (2009), "Indian investment abroad in joint ventures and wholly owned subsidiaries : 2008-09 (AprilMarch)", July 10; (ii) RBI Bulletin (2009), "Indian investment abroad in joint ventures and wholly owned subsidiaries: 2008-09 (April-December)", April 17; (iii) RBI Bulletin (2009), "Indian investment abroad in joint ventures and wholly owned subsidiaries: 2008-09 (April-September)", January 14; (iv) RBI Bulletin (2008), "Indian investment abroad in joint ventures and wholly owned subsidiaries : 2008-09 (April-June)", October 13; and (v) RBI Bulletin (2008), "Indian investment abroad in joint ventures and wholly owned subsidiaries: 2007-08 (April-March)”, July 14.

aThe equity data do not include equity of individuals and banks. Quarterly figures may not add up to annual totals due to revision in data.

Annex table 2. Overseas acquisitions by Indian firms, January-June 2009

\begin{tabular}{|c|c|c|c|c|c|c|}
\hline \multirow{2}{*}{ Month } & \multicolumn{2}{|c|}{$\begin{array}{l}\text { Value } \\
\text { (USD million) }\end{array}$} & \multirow{2}{*}{$\begin{array}{l}\text { \% change } \\
\text { over } \\
\text { previous } \\
\text { year }\end{array}$} & \multicolumn{2}{|c|}{$\begin{array}{l}\text { Number of } \\
\text { deals }\end{array}$} & \multirow{2}{*}{$\begin{array}{l}\text { \% change } \\
\text { over } \\
\text { previous } \\
\text { year }\end{array}$} \\
\hline & 2008 & 2009 & & 2008 & 2009 & \\
\hline January & 1304 & 29 & -97.8 & 28 & 6 & -78.6 \\
\hline February & 602 & 132 & -78.1 & 19 & 5 & -73.7 \\
\hline March & 3019 & 2316 & $-23 \cdot 3$ & 23 & 10 & -56.5 \\
\hline April & 746 & 40 & -94.6 & 28 & 1 & -96.4 \\
\hline May & 569 & 54 & -90.5 & 19 & 4 & -78.9 \\
\hline June & 1731 & 243 & -86.0 & 23 & 2 & -91.3 \\
\hline $\begin{array}{l}\text { All above } \\
\text { months }\end{array}$ & 7971 & 2814 & -64.7 & 140 & 28 & -80.0 \\
\hline
\end{tabular}

Sources: Based on a dataset constructed from reports from newspapers, magazines and financial consulting firms like Hindu Business Line, Economic Times, Financial Express, Business World, Grant Thornton India, and ISI Emerging Markets.

Annex table 3. Sectoral composition of Indian overseas acquisitions, 2008 and early 2009

\begin{tabular}{|c|c|c|c|c|c|c|}
\hline \multirow[b]{2}{*}{ Sector } & \multicolumn{2}{|c|}{ Value (USD million) } & \multirow{2}{*}{$\begin{array}{l}\text { \% change } \\
\text { over } \\
\text { previous } \\
\text { year }\end{array}$} & \multicolumn{2}{|c|}{ Value (USD million) } & \multirow{2}{*}{$\begin{array}{l}\text { \% change } \\
\text { over } \\
\text { previous } \\
\text { year }\end{array}$} \\
\hline & $\begin{array}{l}2007 \\
\text { (Jan.-Dec.) }\end{array}$ & $\begin{array}{l}2008 \\
\text { (Jan.-Dec.) }\end{array}$ & & $\begin{array}{l}2008 \\
\text { (Jan.- } \\
\text { Jun.) }\end{array}$ & $\begin{array}{l}2009 \\
\text { (Jan.- } \\
\text { Jun.) }\end{array}$ & \\
\hline Primary & 2314 & 2533 & 9.5 & 411 & 2230 & 442.6 \\
\hline $\begin{array}{l}\text { Agricultural \& allied } \\
\text { products }\end{array}$ & 10 & 24 & 140 & 24 & & -100 \\
\hline Mining & 1239 & 421 & -66 & 277 & 1780 & 542.6 \\
\hline Oil \& natural gas & 1065 & 2088 & 96.1 & 110 & 450 & 309.1 \\
\hline Manufacturing & 29919 & 6306 & -78.9 & 5394 & 319 & -94.1 \\
\hline Food \& beverages & 1269 & 56 & -95.6 & 54 & & -100 \\
\hline Textiles \& apparel & 126 & 136 & 7.9 & 136 & 119 & -12.5 \\
\hline Paper \& paper & & 9 & & 9 & & -100 \\
\hline
\end{tabular}




\begin{tabular}{|c|c|c|c|c|c|c|}
\hline \multicolumn{7}{|l|}{ products } \\
\hline & 43 & 40 & -7 & 40 & & -100 \\
\hline $\begin{array}{l}\text { Rubber \& plastic } \\
\text { products }\end{array}$ & 65 & 124 & 90.8 & 68 & & -100 \\
\hline $\begin{array}{l}\text { Non-metallic mineral } \\
\text { products }\end{array}$ & 37 & 9 & $-75 \cdot 7$ & 9 & & -100 \\
\hline $\begin{array}{l}\text { Metal \& fabricated } \\
\text { metal products }\end{array}$ & 22346 & 162 & -99.3 & 162 & & -100 \\
\hline $\begin{array}{l}\text { Machinery \& } \\
\text { equipment }\end{array}$ & 1351 & 173 & -87.2 & 152 & & -100 \\
\hline $\begin{array}{l}\text { Electrical machinery \& } \\
\text { equipment }\end{array}$ & $\& \quad 1560$ & 827 & -47 & 556 & 164 & -70.5 \\
\hline Transport equipment & 475 & 2758 & 480.6 & 2701 & 32 & -98.8 \\
\hline $\begin{array}{l}\text { Telecommunication } \\
\text { equipment }\end{array}$ & 757 & & -100 & & & \\
\hline Chemicals & 1117 & 1427 & 27.8 & 1087 & & -100 \\
\hline Pharmaceuticals & 773 & 585 & -24.3 & 420 & 4 & -99 \\
\hline Services & 3350 & 3989 & 19.1 & 2137 & 265 & -87.6 \\
\hline Business advisory & 9 & & -100 & & & \\
\hline $\begin{array}{l}\text { Media \& } \\
\text { entertainment }\end{array}$ & 81 & 148 & 82.7 & 144 & 25 & -82.6 \\
\hline Hospitality \& tourism & 521 & 45 & -91.4 & 45 & 13 & -71.2 \\
\hline $\begin{array}{l}\text { Banking \& financial } \\
\text { services }\end{array}$ & 26 & 141 & 442.3 & 110 & & -100 \\
\hline $\begin{array}{l}\text { Telecommunication } \\
\text { services }\end{array}$ & 330 & 84 & -74.5 & 84 & 26 & -69 \\
\hline IT \& ITES & 2383 & 2565 & 7.6 & 786 & 201 & -74.4 \\
\hline $\begin{array}{l}\text { Power generation \& } \\
\text { distribution }\end{array}$ & & 1006 & & 968 & & -100 \\
\hline Others & 244 & 126 & -48.4 & 29 & & -100 \\
\hline Grand total & 35827 & 12954 & -63.8 & 7971 & 2814 & -64.7 \\
\hline \multicolumn{7}{|c|}{$\begin{array}{l}\text { Sources: Based on a dataset constructed from reports from newspapers, magazines and financial consulting firms like Hindu Business } \\
\text { Line, Economic Times, Financial Express, Business World, Grant Thornton India, and ISI Emerging Markets. }\end{array}$} \\
\hline \multicolumn{7}{|c|}{ Annex table 4. Regional direction of Indian overseas acquisitions, 2008 and early 2009} \\
\hline \multirow{2}{*}{ Host region } & \multicolumn{2}{|c|}{ Value (USD million) } & \multirow{2}{*}{$\begin{array}{l}\text { \% change } \\
\text { over } \\
\text { previous } \\
\text { year }\end{array}$} & \multicolumn{2}{|c|}{ Value (USD million) } & \multirow{2}{*}{$\begin{array}{l}\text { \% change } \\
\text { over } \\
\text { previous } \\
\text { year }\end{array}$} \\
\hline & $\begin{array}{l}2007 \\
\text { (Jan.-Dec.) }\end{array}$ & $\begin{array}{l}2008 \\
\text { (Jan.-Dec.) }\end{array}$ & & $\begin{array}{l}\text { 20o8 } \\
\text { (Jan.- } \\
\text { Jun.) }\end{array}$ & $\begin{array}{l}2009 \\
\text { (Jan.- } \\
\text { Jun.) }\end{array}$ & \\
\hline $\begin{array}{l}\text { Developing } \\
\text { economies }\end{array}$ & 3234 & 685 & -78.8 & 496 & 531 & 7.1 \\
\hline Africa & 111 & 188 & 69.4 & 80 & 451 & 463.8 \\
\hline $\begin{array}{l}\text { Latin America \& } \\
\text { Caribbean }\end{array}$ & 232 & 68 & -70.7 & 68 & & -100 \\
\hline Asia & 2891 & 429 & -85.2 & 348 & 80 & -77 \\
\hline $\begin{array}{l}\text { Transition } \\
\text { economies }\end{array}$ & 37 & 20 & $-45 \cdot 9$ & & & \\
\hline Europe & 37 & 20 & $-45 \cdot 9$ & & & \\
\hline $\begin{array}{l}\text { Developed } \\
\text { economies }\end{array}$ & 32556 & 12249 & -62.4 & 7475 & 2283 & -69.5 \\
\hline America & 14372 & 3570 & -75.2 & 2313 & 2046 & -11.5 \\
\hline Asia & 492 & & -100 & & & \\
\hline Europe & 17579 & 8122 & -53.8 & 4997 & 196 & -96.1 \\
\hline
\end{tabular}




\begin{tabular}{|c|c|c|c|c|c|c|}
\hline Oceania & 113 & 557 & 392.9 & 165 & 41 & -75.2 \\
\hline Grand Total & 35827 & 12954 & -63.8 & 7971 & 2814 & -64.7 \\
\hline \multicolumn{7}{|l|}{ Memorandum item } \\
\hline $\begin{array}{l}\text { Number of host } \\
\text { countries }\end{array}$ & 40 & 42 & & 35 & 14 & \\
\hline $\begin{array}{l}\text { Number of acquiring } \\
\text { Indian companies }\end{array}$ & 150 & 164 & & 109 & 24 & \\
\hline
\end{tabular}

Annex table 5. Indian overseas acquisitions by selected host countries, 2008 and early 2009

\begin{tabular}{|c|c|c|c|c|c|c|}
\hline \multirow[b]{2}{*}{$\begin{array}{l}\text { Host } \\
\text { economy }\end{array}$} & \multicolumn{2}{|c|}{ Value (USD million) } & \multirow{2}{*}{$\begin{array}{l}\text { \% change } \\
\text { over } \\
\text { previous } \\
\text { year }\end{array}$} & \multicolumn{2}{|c|}{ Value (USD million) } & \multirow[b]{2}{*}{$\begin{array}{l}\text { \% change } \\
\text { over } \\
\text { previous year }\end{array}$} \\
\hline & $\begin{array}{l}2007 \\
\text { (Jan.-Dec.) }\end{array}$ & $\begin{array}{l}2008 \\
\text { (Jan.-Dec.) }\end{array}$ & & $\begin{array}{l}2008 \\
\text { (Jan.- } \\
\text { Jun.) }\end{array}$ & $\begin{array}{l}2009 \\
\text { (Jan.- } \\
\text { Jun.) }\end{array}$ & \\
\hline UK & 15374 & 5384 & -65.0 & 2681 & 32 & -98.8 \\
\hline USA & 12003 & 3165 & -73.6 & 1932 & $2045 \cdot 94$ & $5 \cdot 9$ \\
\hline Canada & 1805 & 405 & -77.6 & 381 & & -100.0 \\
\hline Indonesia & 1124 & 258 & -77.0 & 258 & 80 & -69.0 \\
\hline Norway & 900 & 302 & -66.4 & 300 & & -100.0 \\
\hline Singapore & 818 & 39 & -95.2 & 22 & & -100.0 \\
\hline $\begin{array}{l}\text { Republic of } \\
\text { Korea }\end{array}$ & 752 & & -100.0 & & & \\
\hline Germany & 745 & 812 & 9.0 & 554 & 164 & -70.4 \\
\hline Bermuda & 564 & & -100.0 & & & \\
\hline Israel & 489 & & -100.0 & & & \\
\hline Netherlands & 355 & 954 & 168.7 & 954 & & -100.0 \\
\hline Brazil & 224 & & -100.0 & & & \\
\hline Malaysia & 133 & & -100.0 & & & \\
\hline Australia & 113 & 557 & 392.9 & 165 & 41 & -75.2 \\
\hline Mozambique & 86 & 78 & -9.3 & & & \\
\hline France & 71 & 35 & -50.7 & 2 & & -100.0 \\
\hline Italy & 61 & 272 & 345.9 & 187 & & -100.0 \\
\hline Vietnam & 44 & 2 & -95.5 & & & \\
\hline Russia & 37 & 20 & $-45 \cdot 9$ & & & \\
\hline Czech Republic & 25 & 3 & -88.0 & 3 & & -100.0 \\
\hline
\end{tabular}

\section{Annex table 6. Illustrative cases of overseas disinvestment by Indian firms, 2009}

\section{Indian company Action taken}

Suzlon Energy Ltd. SEL sold 10\% stake in Hansen Transmissions International on January 2, 2009 to raise Rs 600 crore (about USD120 million). According to news reports, Suzlon has taken this step because of the tight liquidity situation and its obligation to buy the stake of the Portuguese company Martifer in REpower, Germany.

Sakthi Sugars Ltd. Sakthi Germany GmbH and Sakthi Sweden AB have filed for bankruptcy and Arvika Gjuteri AB, Sweden, for financial reconstruction. According to a parent 
company source, these measures were taken on account of the economic meltdown in the US and Europe and the consequent drastic reduction in orders.

Reliance Industries Ltd.

Vardhman Polytex Ltd.
RIL's German subsidiary, Trevira $\mathrm{GmbH}$, has started insolvency proceedings. RIL took this step to overcome the impact of the industrial slowdown in Europe, particularly in the automotive and textile sectors, to which it is an important supplier.

VPL has decided to close down its Austrian subsidiary, FM Hammerle Nfg $\mathrm{GmbH}$, as part of a business restructuring demanded by the current recession in Europe.

Sources: (i) Hindu Business Line (2009), "Suzlon Energy sells 10\% stake in Hansen", January 3; (ii) Financial Express (2009), "Sakthi Sugars' European units file for bankruptcy", February 6; (iii) Economic Times (2009), "RIL's German textile arm files for bankruptcy", June 4; and (iv) BSE (2009), "Corporate communication of Vardhman Polytex", June 23.

The material in this Perspective may be reprinted if accompanied by the following acknowledgment: "Jaya Prakash Pradhan, 'Indian FDI falls in global economic crisis: Indian multinationals tread cautiously,' Columbia FDI Perspectives, No. 11, August 17, 2009. Reprinted with permission from the Vale Columbia Center on Sustainable International Investment (www.vcc.columbia.edu)." A copy should kindly be sent to the Vale Columbia Center at vec@law.columbia.edu.

For further information please contact: Vale Columbia Center on Sustainable International Investment, Karl P. Sauvant, Executive Director, (212) 854-0689, Karl.Sauvant@law.columbia.edu or Lisa Sachs, Assistant Director, (212) 854-0691, Lsachs1@law.columbia.edu.

Vale Columbia Center on Sustainable International Investment (VCC), led by Dr. Karl P. Sauvant, is a joint center of Columbia Law School and The Earth Institute at Columbia University. It seeks to be a leader on issues related to foreign direct investment (FDI) in the global economy. VCC focuses on the analysis and teaching of the implications of FDI for public policy and international investment law.

\section{Previous Columbia FDI Perspectives}

- No. 1. Karl P. Sauvant, "The FDI Recession has Begun,” November 22, 2008.

- No. 2. Mark E. Plotkin and David N. Fagan, "The Revised National Security Review Process for FDI in the US, ” January 7, 2009.

- No. 3. Anne van Aaken and Jürgen Kurtz, "The Global Financial Crisis: Will State Emergency Measures Trigger International Investment Disputes?” March 23, 2009.

- No. 4. Gert Bruche, "A New Geography of Innovation-China and India Rising,” April 29, 2009.

- No. 5. Ken Davies, "While Global FDI Falls, China's Outward FDI Doubles," May 26, 2009.

- No. 6. Christian Bellak and Markus Leibrecht, "Improving infrastructure or lowering taxes to attract foreign direct investment?" June 3, 2009.

- No. 7. Susan D. Franck, "International Investment Arbitration: Winning, Losing and Why," June 15, 2009.

- No. 8. Lorenzo Cotula, "Land grab or development opportunity? International farmland deals in Africa," June 22, 2009.

- No. 9. Veljko Fotak and William Megginson, “Are SWFs Welcome Now?” July 22, 2009.

- No. 10. Subrata Bhattacharjee, "National Security with a Canadian Twist: The Investment Canada Act and the New National Security Review Test," July 30, 2009. 